\title{
PENGEMBANGAN MODEL PEMBELAJARAN SEJARAH LOKAL DI SMA KOTA MADIUN
}

\author{
Anjar Mukti Wibowo*
}

\begin{abstract}
Abstrak
Penelitian ini bertujuan untuk menghasilkan model pembelajaran berbasis situs sejarah lokal bagi siswa sekolah menengah atas di Madiun. Sejarah lokal penting sebagai sumber pembelajaran sejarah karena memungkinkan siswa untuk berhubungan secara sangat "intim" dengan peristiwa yang sangat lokal dan mungkin selama ini dianggap tidak besar, tetapi sesungguhnya memiliki peran penting dan berharga dalam membentuk peristiwa yang lebih besar. Penelitian ini merupakan penelitian dan pengembangan. Model pengembangan dalam penelitian ini adalah model prosedural. Prosedur atau langkah penelitian dan pengembangan merujuk pada siklus $R$ \& D dari Borg dan Gall (1983:626) yang meliputi kegiatan: pengumpulan informasi dan identifikasi masalah, perencanaan model, pengembangan model awal, uji terbatas, revisi model, uji skala kecil, revisi model, uji skala besar, revisi model, model akhir, diseminasi dan implementasi. Penelitian dilakukan selama dua tahun. Hasil penelitian menemukan masalah-masalah yang muncul disebabkan adanya penolakan dari sekolah ketika lawatan sejarah, keterbatan waktu jam pelajaran dan transportasi ke lokasi. Berdasarkan pemetaan kebutuah yang ditemukan, selanjutnya disusun draf model pemanfaatan situs sejarah lokal Madiun sebagai sumber pembelajaran. Draf model tersebut diujikan kepada ahli pembelajaran sejarah. Hasil kegiatan tersebut adalah model awal pengembangan model pemanfaatan situs sejarah lokal sebagai sumber pembelajaran di Sekolah Menengah Atas Kota Madiun yang diujicobakan pada tahun kedua.
\end{abstract}

\section{Kata Kunci: Situs, Sejarah Lokal, Pembelajaran.}

\section{Pendahuluan}

\section{A. Latar Belakang}

Madiun merupakan kota bersejarah. Berbagai peristiwa di masa lalu meninggalkan jejak-jejak sejarah yang penting, baik bagi masyarakat lokal maupun masyarakat Indonesia pada umumnya. Jejakjejak sejarah tersebut diantaranya berupa tempat atau situs bersejarah dan peninggalan benda-benda bersejarah.

Situs bersejarah merupakan tempat yang memiliki nilai sejarah. Suatu tempat dikatakan memiliki nilai sejarah antara lain apabila di tempat tersebut terdapat benda atau peninggalan bersejarah; merupakan tempat kelahiran, kemangkatan, dan makam tokoh penting; atau merupakan ajang peristiwa penting tertentu terjadi, yang dalam disiplin sejarah disebut dengan peristiwa pada masa lampau yang memiliki signifikansi sosial.

Situs bersejarah berkaitan erat dengan sejarah lokal. Situs bersejarah mengandung sejarah lokal dan sejarah lokal biasanya muncul di tempat-tempat bersejarah. Sejarah lokal di Indonesia masih belum banyak ditulis, karena keterbatasan sumber. Sejarah lokal di suatu lokalitas tertentu masih berupa kisah-kisah yang dituturkan secara lisan. Kisah-kisah tersebut merupakan memori kolektif masyarakat. Sejarah lokal ditransmisikan secara lisan dari satu generasi ke generasi yang lain, sehingga dalam kasus-kasus tertentu sejarah lokal merupakan tradisi lisan yang dari waktu ke waktu dapat mengalami perubahan (Taufik Abdullah, 1990:15).

Di era otonomi daerah, sejarah lokal semakin penting keberadaannya. Sejarah tidak hanya memiliki narasi besar yang 
berkisah tentang tokoh-tokoh dengan seluruh tindakan historisnya. Sejarah, juga mengandung banyak serpihan yang mengandung narasi kecil tentang bangunan dengan seluruh pernik-perniknya, kisah manusia yang terjadi di dalam kemelut persoalan politik, sosial, budaya, dan hal-hal lain yang layak diketahui sebagai referensi bagi generasi demi generasi.

Otonomi daerah meniscayakan kemandirian masyarakat di daerah. Kemandirian daerah adalah terbangunnya jati diri daerah. Jati diri tersebut secara kultural menjadi kebanggaan warga daerah. Sejarah lokal membantu masyarakat daerah menemukan jati dirinya. Secara ekonomis, sejarah lokal juga dapat memberi kontribusi bagi kesejahteraan hidup masyarakat.

Menurut Singgih (2009:4), paling tidak ada dua manfaat sejarah daerah dalam rangka pembangunan di era otonomi daerah yaitu: 1) sejarah daerah sebagai sarana untuk menggali dan menemukan serta membangun jati diri dan kepribadian daerah (character building); 2) sejarah daerah sebagai sarana untuk membangun solidaritas sosial (social solidarity) yang sangat diperlukan dalam pembangunan daerah; 3) sejarah daerah sebagai wahana rujuk sosial.

Di era Otonomi Daerah semua wewenang dan tanggung jawab pembangunan daerah dilimpahkan kepada segenap unsur masyarakat di daerah baik pemerintah daerah (Bupati/ walikota dan segenap birokrasi di bawahnya, DPRD dengan segala perangkatnya, dan unsurunsur pimpinan lain di daerah) maupun berbagai kelompok masyarakat. Unsur Pemerintah Daerah memegang kunci utama dalam kehidupan eksekutif. Pembangunan daerah semestinya dilaksanakan sesuai dengan potensi dan kepribadian yang dimiliki daerah itu sendiri, maka segenap unsur stakeholders harus mengetahui kepribadian macam apa yang dimiliki oleh daerah. Dalam hal ini penelitian dan penulisan sejarah akan memiliki posisi penting sebab hanya dalam sejarahlah kepribadian daerah bisa ditemukan.

Sejarah lokal penting sebagai sumber pembelajaran. Haryono mengatakan bahwa pemanfaatan sejarah lokal di tingkat pendidikan manapun akan memungkinkan peserta didik dalam mempelajari sejarah dapat beresonansi dengan aspek eigenwelt yang dimiliki (Sartono Kartodirdjo dalam Soedarsono, 1986).

Sejarah lokal memungkinkan kita untuk berhubungan secara sangat "intim" dengan peristiwa yang sangat lokal dan mungkin selama ini dianggap tidak besar, tetapi sesungguhnya memiliki peran penting dan berharga dalam membentuk peristiwa yang lebih besar (Taufik Abdullah, 1990:19).

Pemaparan sejarah lokal dapat menjembatani peserta didik dalam memahami berbagai peristiwa sejarah di masyarakat sekitarnya dengan peristiwa sejarah di daerah lain. Melalui kajian sejarah lokal, peserta didik dirangsang untuk dapat melihat proses integrasi nasional sebagai suatu peristiwa sejarah.

Situs sejarah lokal juga memiliki daya tarik wisata. Para wisatawan biasanya ingin melihat keunikan-keunikan yang tidak terdapat di daerah asal dan belum pernah ditemuinya. Bagi wisatawan, tempat bersejarah dengan sejarah lokalnya merupakan suatu keunikan yang menjadi daya tarik wisata. Hal ini setidaknya dapat terungkap dari motivasi seseorang dalam melakukan perjalanan wisata.

Keberadaan situs sejarah amat rawan dari tindak kriminal; dicuri, atau sengaja dijual penduduk lokal kepada penadah benda-benda peninggalan purbakala. Kita tentu tidak ingin satu generasi mendatang, terlepas akar sejarahnya lantaran rusak dan musnahnya situs-situs sejarah. Sebelum terlambat, sudah saatnya pemerintah dibantu masyarakat, melakukan pelacakan riwayat situs penting, baik yang mayor maupun yang minor, dalam bentuk penulisan. Memang ada kesan miring tentang penulisan narasi situs sejarah lokal. Sebagian kalangan menganggap itu pekerjaan sia-sia; karena sudah ada versi lengkap yang ditulis oleh ahli sejarah dari negara lain (Belanda).

Anggapan di atas tidak sepenuhnya benar karena narasi sejarah lokal bukan hanya berguna bagi pembelajaran masyarakat atas sejarah leluhurnya, 
melainkan juga dapat mendukung dinamika pariwisata di tempat itu. Para pelancong dalam dan luar negeri itu, ingin mengetahui kejayaan masa lalu Jogja bukan hanya dari situs-situs belaka. Mereka butuh narasi yang akan memberikan cara pandang baru, dan rasa ketertarikan lebih dalam tentang kota ini. Ketika ketertarikan itu muncul, mereka tentu akan kembali lagi tidak hanya sendirian, tetapi dengan keluarga dan teman-temannya.

Situs bersejarah berkaitan erat dengan sejarah lokal. Sejarah lokal penting sebagai sumber pembelajaran sejarah. Sejarah lokal memungkinkan kita untuk berhubungan secara sangat "intim" dengan peristiwa yang sangat lokal dan mungkin selama ini dianggap tidak besar, tetapi sesungguhnya memiliki peran penting dan berharga dalam membentuk peristiwa yang lebih besar.

Pembelajaran sejarah lokal berarti menyadarkan pada peserta didik bahwa mereka mempunyai masa lalu sendiri. Mereka memiliki suatu kebanggaan bahwa jauh sebelum mereka dilahirkan ada beberapa tokoh yang berperan dalam membentuk keadaan yang terkait dengan masa sekarang. Kesadaran kontunuitas dan lokalitas ini dapat menjadi bekal pada peserta didik untuk menunjukkan identitas historis, sosial, dan budayanya. Semakin jauh peserta didik terlibat dalam eksplorasi sejarah lokal berarti semakin tinggi pula jati diri dan kebanggan akan masa lalu kelompok, daerah, dan kebudayaannya.

Kesadaran terhadap masa lalu daerahnya ini jangan sampai merusak kultur dan budaya yang sudah positif di masyarakat. Artinya jangan sampai peserta didik mempunyai kebanggaan berlebihan sehingga aspek primordial kesukuan dan kedaerahannya lebih ditonjolkan. Hal ini justru akan merusak semangat persatuan dan kebersamaan yang saat ini sudah tercapai dengan baik.

Semakin muncul kesadaran terhadap identitas pelaku sejarah dan peristiwa sejarah harusnya peserta didik tidak terjebak pada spirit primordial yang negatif. Justru dengan menyelami semangat juang sang tokoh, maka peserta didik dapat memahami bagaimana rasa merdeka pelaku sejarah dalam mempertahankan wilayah atau negerinya melawan unsur-unsur kebudayaan dan pemerintahan asing yang menindas.

Dengan sejarah lokal yang diajarkan dalam kelas maupun luar kelas, berarti peserta didik mengenal secara langsung bagaimana pribadi dan biografi hidup sang pelaku sejarah. Mereka dapat menanyakan sisi kehidupan sang pelaku sejarah. Dengan tehnik tanya jawab yang baik peserta didik dapat mengenali dan mentauladani jiwa-jiwa kepemimpinan sang pelaku sejarah secara arif dan bijak. Bagaimana mereka mengorbankan apa saja demi tegaknya sebuah kemerdekaan inilah yang perlu diapresiasi oleh peserta didik dalam pembelajaran sejarah lokal.

Pembelajaran sejarah lokal memberikan peluang lebih aktif bagi peserta didik untuk menggali informasi secara mandiri terhadap sasaran yang sudah direncanakan. Melalui informasi juru kunci, pamong budaya, dan petugas kebudayaan peserta didik menjadi lebih mengenali karakter sosial dari pelaku sejarah. Bagaimana pelaku sejarah memperjuangkan nilai-nilai ideologi yang mulia dan sesuai dengan konteks kebersamaan dalam hidup masa itu akan memberi inspirasi bagi peserta didik untuk mengamalkan hal yang sama pada kehidupan masa sekarang.

Pembelajaran sejarah lokal juga memberikan banyak informasi tentang kebudayaan apa yang berkembang di wilayahnya pada masa lalu. Melalui relief, patung, dan artefak peninggalan HinduBuddha yang tersisa peserta didik dapat melihat bagaimana posisi geografis dan peran sosial ekonomi-politik daerahnya pada waktu itu. Apakah wilayahnya mempunyai peran sosial yang cukup penting ataukah daerahnya menjadi kawasan peripherial saja dari struktur kekuasaan Hindu-Buddha yang berporos Kedu-Bagelen. Kesadaran historis ini dapat menghasilkan semangat untuk melakukan perubahan dalam perspektif yang positif pada masa sekarang. Ketika peserta didik melihat bahwa wilayahnya (lingkungannya) tidak mempunyai peran yang signifikan bagi pemerintahan pusat saat itu, mereka 
terinspirasi untuk melakukan perubahan. Dari beberapa peserta didik muncul daya upaya untuk merubah keadaan dengan menawarkan kekayaan-sumber daya alam dan sumber daya manusia yang dimilikinya sehingga eksistensi masyarakat dan daerahnya dapat diakui daerah-daerah lain. Berarti pula muncul kepercayaan diri peserta didik ketika mereka merefleksikan diri dari apa yang terdapat pada kekayaan historisnya.

Dengan pembelajaran sejarah lokal berarti peserta didik dapat mengambil hikmah gaya kepemimpinan pelaku sejarah yang dapat diterapkan oleh peserta didik pada saat mereka menempati posisi dan profesi pekerjaan masing-masing. Semangat pelaku sejarah yang mengutamakan musyawarah mufakat dalam memutuskan sesuatu hal memberikan dorongan bagi peserta didik dalam memutuskan suatu kebijakan kelak ketika mereka sudah bekerja. Semangat gotong royong memberikan inspirasi nyata bagi peserta didik untuk mendorong etos kerja dan produktivitas kerja ketika peserta didik sudah menempati posisi dalam pekerjaan dan perusahaan. Semangat rela berkorban dan mengutamakan kepentingan bersama jelas dapat diterapkan pada iklim dunia kerja tanpa membeda-bedakan latar sosial dan budaya agar perusahaan dapat mencapai prestasi kerja yang tinggi (Enny Boedi Utami, 2007:6).

Di Kota Madiun, situs sejarah lokal belum banyak dimanfaatkan sebagai sumber pembelajaran. Penelitian ini akan mengembangkan model pembelajaran berbasis situs sejarah lokal Kota Madiun.

\section{B. Tujuan Penelitian}

Tujuan khusus penelitian ini adalah dihasilkannya model pemberdayaan situs sejarah lokal sebagai sumber pembelajaran di sekolah Kota Madiun yang diwujudkan dalam bentuk artikel ilmiah dan buku panduan yang implementatif. Hasil penelitian dipublikasikan dalam jurnal ilmiah nasional terakreditasi yaitu Jurnal Ilmu Pendidikan Universitas Negeri Malang.

\section{Metode Penelitian}

Penelitian ini merupakan tindak lanjut dari penelitian dengan judul, "Narasi Situs Sejarah Lokal Sebagai Sumber Pembelajaran" yang menghasilkan identifikasi faktor-faktor penyebab situs sejarah lokal banyak yang tidak terkelola dan belum diberdayakan sebagai sumber pembelajaran serta rumusan konseptual pemanfaatan situs sejarah lokal sebagai sumber pembelajaran di sekolah.

Penelitian ini akan menerapkan rumusan tersebut menjadi model operasional pemanfaatan situs sejarah lokal sebagai sumber pembelajaran di sekolah Kota Madiun. Metode yang digunakan adalah metode penelitian dan pengembangan. Metode ini digunakan untuk menghasilkan produk tertentu dan menguji efektivitas produk tersebut (Sugiyono, 2006:407). Produk dalam konteks penelitian ini adalah model pemberdayaan situs sejarah lokal sebagai sumber pembelajaran di sekolah Kota Madiun.

Model pengembangan dalam penelitian ini adalah model prosedural. Prosedur atau langkah penelitian dan pengembangan merujuk pada siklus $\mathrm{R} \& \mathrm{D}$ dari Borg dan Gall (1983:626) yang meliputi kegiatan: pengumpulan informasi dan identifikasi masalah, perencanaan model, pengembangan model awal, uji terbatas, revisi model, uji skala kecil, revisi model, uji skala besar, revisi model, model akhir, diseminasi dan implementasi.

Penelitian dilakukan selama dua tahun. Sebagai langkah awal pada tahun pertama, dilakukan pengumpulan informasi dan identifikasi masalah terkait dengan model pemberdayaan situs sejarah lokal sebagai sumber pembelajaran di sekolah Kota Madiun. Data dan informasi diperoleh melalui wawancara mendalam dengan para pemimpin instansi terkait seperti Dinas Pendidikan, Kepala Sekolah, dan Guru.

Hasil identifikasi masalah tersebut selanjutnya dikembangkan melalui serangkaian Focus Group Discusion (FGD) dengan mengundang para pakar pembelajaran sejarah. Hasil kegiatan tersebut adalah model awal pengembangan 
model pemanfaatan situs sejarah lokal sebagai sumber pembelajaran di sekolah Kota Madiun.

Model tersebut kemudian dikembangkan dalam bentuk panduan yang berisi paparan model pemanfaatan situs sejarah lokal sebagai sumber pembelajaran di sekolah Kota Madiun serta langkah-langkah strategis pengembangan model pemanfaatan situs sejarah lokal sebagai sumber pembelajaran di sekolah Kota Madiun sebagai hasil penelitian tahun pertama.

Buku panduan tersebut diujicobakan untuk melihat efektivitasnya sebagai sumber pembelajaran di sekolah Kota Madiun. Panduan diujicobakan dalam skala kecil di 3 sekolah yang diambil secara random. Subjek uji coba adalah para guru. Data dikumpulkan dengan teknik wawancara mendalam, selanjutnya dianalisis secara deskriptif kualitatif. Hasil ujicoba disampaikan kepada para ahli pembelajaran sejarah.

Buku panduan diujicobakan dalam skala kecil kemudian diujicobakan dalam skala besar kepada masyarakat Madiun di 6 sekolah yang diambil dengan teknik random. Subjek uji coba adalah para guru. Data dikumpulkan dengan teknik wawancara mendalam, selanjutnya dianalisis secara deskriptif kualitatif. Hasil ujicoba disampaikan kepada para ahli pembelajaran sejarah untuk memberikan saran perbaikan melalui FGD.

Saran dan data yang masuk dari lapangan operasional digunakan untuk melakukan revisi terhadap produk akhir. Di akhir siklus ini produk buku panduan didesiminasikan dan siap diimplementasikan. Diseminasi dilakukan melalui penulisan di jurnal ilmiah nasional terakreditasi (Jurnal Ilmu Pendidikan Universitas Negeri Malang) sebagai hasil penelitian tahun kedua. Dengan demikian uji coba produk dilakukan sebanyak tiga kali yaitu uji ahli, uji lapangan skala kecil, dan uji coba skala besar. Soenarto (dalam Tim Penatar PPKP, 2005:9) menyebutnya dengan uji ahli atau validasi, uji terbatas, dan uji lapangan.

Indikator capaian dari penelitian ini, dengan demikian adalah model pemanfaatan situs sejarah lokal sebagai sumber pembelajaran di sekolah Kota Madiun yang diwujudkan dalam bentuk artikel ilmiah dalam jurnal ilmiah nasional terakreditasi. Tahapan penelitian selengkapnya dapat dilihat pada bagan berikut.

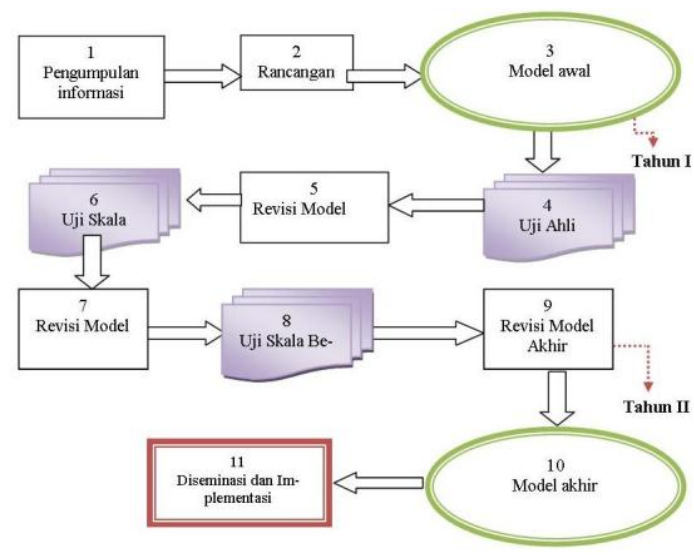

Bagan 2 : Bagan Alir Penelitian

\section{Hasil Penelitian dan Pembahasan}

\section{A. Potensi Situs Sejarah Lokal}

Madiun merupakan kota bersejarah. Berbagai peristiwa di masa lalu meninggalkan jejak-jejak sejarah yang penting, baik bagi masyarakat lokal maupun masyarakat Indonesia pada umumnya. Jejakjejak sejarah tersebut diantaranya berupa tempat atau situs bersejarah dan peninggalan benda-benda bersejarah. Situs bersejarah merupakan tempat yang memiliki nilai sejarah. Suatu tempat dikatakan memiliki nilai sejarah antara lain apabila di tempat tersebut terdapat benda atau peninggalan bersejarah; merupakan tempat kelahiran, kemangkatan, dan makam tokoh penting; atau merupakan ajang peristiwa penting tertentu terjadi, yang dalam disiplin sejarah disebut dengan peristiwa pada masa lampau yang memiliki signifikansi sosial.

Situs bersejarah biasanya berkaitan erat dengan sejarah lokal. Situs bersejarah mengandung sejarah lokal dan sejarah lokal biasanya muncul di tempat-tempat bersejarah. Sejarah lokal mengandung nilainilai lokal yang dapat memperkaya nilai-nilai kebangsaan. Di Madiun cukup banyak situs bersejarah seperti Situs Candi Wonoredjo, Prasasti Mruwak, Klagen Serut, Bibrik, 
bekas gedung Residen Belanda, Prasasti Kutu, Prasasti Sendang Kamal, dan Monumen Kresek yang menggambarkan sejarah peristiwa Pembrontakan PKI di Madiun tahun 1948.

Salah satu indikator pengajaran sejarah yang berhasil adalah mampu menjadikan peserta didik tertarik dan semakin bersemangat dalam belajar sejarah. Gambaran dan kebutuhan masyarakat di masa kini dan masa depan bagi peserta didik harus dipahami oleh pendidik. Gambaran dan kebutuhan masyarakat di masa depan tentu saja tidak dapat dijelaskan sepenuhnya, namun ada beberapa aspek yang dapat diketahui dan diperkirakan sebagai gambaran untuk mempersiapkan peserta didik menghadapi tantangan zamannya. Terkait dengan hal tersebut, maka interaksi antara hasil belajar yang diharapkan dengan kondisi belajar yang dibutuhkan menjadi penting untuk diperhatikan.

Kesadaran terhadap masa lalu daerahnya ini jangan sampai merusak kultur dan budaya yang sudah positif di masyarakat. Artinya jangan sampai peserta didik mempunyai kebanggaan berlebihan sehingga aspek primordial kesukuan dan kedaerahannya lebih ditonjolkan. Hal ini justru akan merusak semangat persatuan dan kebersamaan yang saat ini sudah tercapai dengan baik.

Semakin muncul kesadaran terhadap identitas pelaku sejarah dan peristiwa sejarah harusnya peserta didik tidak terjebak pada spirit primordial yang negatif. Justru dengan menyelami semangat juang sang tokoh, maka peserta didik dapat memahami bagaimana rasa merdeka pelaku sejarah dalam mempertahankan wilayah atau negerinya melawan unsur-unsur kebudayaan dan pemerintahan asing yang menindas.

Dengan sejarah lokal yang diajarkan dalam kelas maupun luar kelas, berarti peserta didik mengenal secara langsung bagaimana pribadi dan biografi hidup sang pelaku sejarah. Mereka dapat menanyakan sisi kehidupan sang pelaku sejarah. Dengan tehnik tanya jawab yang baik peserta didik dapat mengenali dan mentauladani jiwa-jiwa kepemimpinan sang pelaku sejarah secara arif dan bijak. Bagaimana mereka mengorbankan apa saja demi tegaknya sebuah kemerdekaan inilah yang perlu diapresiasi oleh peserta didik dalam pembelajaran sejarah lokal.

Pembelajaran sejarah lokal memberikan peluang lebih aktif bagi peserta didik untuk menggali informasi secara mandiri terhadap sasaran yang sudah direncanakan. Melalui informasi juru kunci, pamong budaya, dan petugas kebudayaan peserta didik menjadi lebih mengenali karakter sosial dari pelaku sejarah. Bagaimana pelaku sejarah memperjuangkan nilai-nilai ideologi yang mulia dan sesuai dengan konteks kebersamaan dalam hidup masa itu akan memberi inspirasi bagi peserta didik untuk mengamalkan hal yang sama pada kehidupan masa sekarang.

Pembelajaran sejarah lokal juga memberikan banyak informasi tentang kebudayaan apa yang berkembang di wilayahnya pada masa lalu. Melalui relief, patung, dan artefak peninggalan HinduBudha yang tersisa peserta didik dapat melihat bagaimana posisi geografis dan peran sosial ekonomi-politik daerahnya pada waktu itu. Apakah wilayahnya mempunyai peran sosial yang cukup penting ataukah daerahnya menjadi kawasan peripherial saja dari struktur kekuasaan Hindu-Buddha yang berporos Kedu-Bagelen. Kesadaran historis ini dapat menghasilkan semangat untuk melakukan perubahan dalam perspektif yang positif pada masa sekarang. Ketika peserta didik melihat bahwa wilayahnya (lingkungannya) tidak mempunyai peran yang signifikan bagi pemerintahan pusat saat itu, mereka terinspirasi untuk melakukan perubahan. Dari beberapa peserta didik muncul daya upaya untuk merubah keadaan dengan menawarkan kekayaan-sumber daya alam dan sumber daya manusia yang dimilikinya sehingga eksistensi masyarakat dan daerahnya dapat diakui daerah-daerah lain. Berarti pula muncul kepercayaan diri peserta didik ketika mereka merefleksikan diri dari apa yang terdapat pada kekayaan historisnya.

Dengan pembelajaran sejarah lokal berarti peserta didik dapat mengambil 
hikmah gaya kepemimpinan pelaku sejarah yang dapat diterapkan oleh peserta didik pada saat mereka menempati posisi dan profesi pekerjaan masing-masing. Semangat pelaku sejarah yang mengutamakan musyawarah mufakat dalam memutuskan sesuatu hal memberikan dorongan bagi peserta didik dalam memutuskan suatu kebijakan kelak ketika mereka sudah bekerja. Semangat gotong royong memberikan inspirasi nyata bagi peserta didik untuk mendorong etos kerja dan produktivitas kerja ketika peserta didik sudah menempati posisi dalam pekerjaan dan perusahaan. Semangat rela berkorban dan mengutamakan kepentingan bersama jelas dapat diterapkan pada iklim dunia kerja tanpa membeda-bedakan latar sosial dan budaya agar perusahaan dapat mencapai prestasi kerja yang tinggi (Enny Boedi Utami, 2007:6).

\section{A. Masalah Dalam Pembelajaran Sejarah Lokal}

Materi pembelajaran sejarah lokal di sekolah di Madiun antara lain TRIP, G30S PKI, PKI Madiun 1948, dan Gerbang Maut (Soco), dan Retno Dumilah, tetapi ini tidak ada dalam kurikulum sejarah. Guru hanya menyinggungnya dengan menarik hubungan dengan kerajaan-kerajaan di Jawa. Bahwa sosok Retno Dumilah itu memiliki hubungan dengan kerajaan di Jawa Tengah. Soco adalah nama sebuah desa yang letaknya kurang lebih lima ratus meter di sebelah Selatan Lapangan Udara Iswahyudi. Soco termasuk wilayah Kecamatan Bendo Kabupaten Magetan. Desa Soco dalam peristiwa berdarah yang dilakukan oleh FDR/PKI tahun 1948 memiliki arti sejarah tersendiri. Hal ini dikarenakan di desa Soco inilah para tokoh dianggap musuh oleh FDR/PKI dibantai secara masal di dalam sumur-sumur tua di tengah tegalan.

Letak desa Soco cukup strategis, disamping dekat lapangan Udara Iswahyudi, juga dilintasi re-rel kereta Lori dari daerah perkebunan tebu menuju berbagai pabrik gula seperti pabrik gula Pagotan, Kanigoro, Glodok dan Pabrik gula Rejosari di Goranggareng. Di desa Soco terdapat sumur-sumur tua di temgah tegalan yag sangat memungkinkan untuk dipakai sebagai lubang pembantaian karena letaknya jauh dari pemukiman penduduk. Sebelum peristiwa berdarah itu terjadi, warga masyarakat desa Soco sudah mulai merasakan adanya aksi-aksi yang dilakukan oleh orang-orang PKI; pencurian, perampokan dan penculikan berlangsung dengan semena-mena, yang menjadi korban senantiasa orang-orang yang bukan PKI. Kejadian itu mencapai puncak-nya pada tanggal 18 September 1948. Menurut salah seorang saksi bernama Jalim Anshori, pada saat itu beratus-ratus manusia memakai gelang janur di bawah pimpinan Rusdi bergerak menuju rumah Lurah Tanjung Soemoatmodjo sambil berteriak-teriak, "Sayap kanan tutup! Sayap kiri hidup." Setelah berhasil menangkap lurah Tanjung Samoatmojo digiring ke Soco untuk dibantai.

Selanjutnya orang-orang PKI bergerak menuju rumah sakit salah seorang tokoh Nasionalis, setelah tertangkap Sakidi diikat disana. Mendengar suaminya telah dibantai, Nyonya Sadiki segera menyusul ke Soco. Setelah tiba di Soco dia sudah tidak bisa menjumpai suaminya lagi, tetapi dia nekat ingin melihat jenazahnya, namun akhirnya dia juga dibantai dan mayatnya dimasukkan ke dalam sumur itu juga. Sumur-sumur tua di Soco tersebut dirancang sedemikian rupa oleh PKI dijadikan basis untuk membantai para tokoh yang dianggap lawan.

Metode yang digunakan adalah diskusi, lawatan sejarah, juga penugasan. Lawatan sejarah dilakukan di Kresek. Sebelum kunjungan pertama-tama membagi siswa ke dalam kelompok-kelompok. Selanjutnya setiap kelompok diberi tugas apa yang akan dipelajari di tempat kunjungan sejarah. Setelah kunjungan, siswa membuat laporan berupa makalah kelompok. Salah satu perwakilan kelompok dipresentasikan di depan kelas. Di lapangan muncul pertanyaan-pertanyaan kritis yang harus dicari jawabannya oleh siswa. Waktunya hari Minggu, jadi di luar jam sekolah. Anak-anak dibebaskan untuk berkunjung sendiri secara berkelompok karena lokasinya dekat.

Masalah yang muncul disebabkan materi sejarah lokal Madiun yang tidak ada dalam kurikulum dan waktunya yang 
terbatas hanya 1 jam pelajaran. Pada mulanya ada penolakan dari sekolah ketika lawatan sejarah karena bisa mengganggu kegiatan belajar mengajar, tapi itu hanya satu kali. Kemudian dijelaskan kepada kepala sekolah bahwa waktunya di luar jam sekolah sehingga akhirnya mengijinkan.

Kurikulum 2013 memberi kesempatan yang lebih leluasa kepada sejarah. Ke depan lawatan sejarah bisa dirancang satu hari penuh pada hari Sabtu dan untuk semua kelas. Sekolah tentu akan mendukung dan mengijinkan mengingat kurikulum yang digunakan adalah kurikulum 2013 yang lebih menonjolkan sejarahnya dan mewajibkan siswa untuk mencaritahu sendiri.

\section{B. Model Pembelajaran Sejarah Berbasis Situs Sejarah Lokal}

Pengajaran sejarah lokal merupakan bagian dari proses belajar di lingkungan pendidikan formal, sasaran utamanya tentunya adalah keberhasilan proses itu sendiri dalam mencapai tujuan yang telah ditetapkan dalam kurikulum. Berbeda dari studi sejarah lokal yang lebih ditekankan pada pencapaian pengetahuan tentang peristiwa sejarah yang dijadikan sasaran studi yakni sejarah dari suatu lokalitas tertentu. Untuk itu pengajaran sejarah lokal di sekolah-sekolah hendaknya dipandang sebagai salah satu alternatif yang mungkin dapat dipilih dan diterapkan dengan membawa siswa pada apa yang sering disebut Living History, yaitu sejarah dari lingkungan sekitar dirinya.

Dasar utama dari pilihan mengapa harus sejarah lokal sebagai alternatif ialah kemungkinan pengembangan wawasan dalam pengajaran sejarah. Diharapkan murid bisa lebih bergairah dalam mengikuti pelajaran dan mendapatkan manfaat lebih besar dari proses pembelajaraannya. Pendekatan ataupun metode pengajaran sangat beragam dan masing-masing punya kelebihan sekaligus kelemahan, oleh karenanya pilihan suatu pendekatan pengajaran akan sangat tergantung pada tujuan atau sasaran yang dicapai.

Melalui pengajaran sejarah lokal siswa diajak mendekatkan diri pada situasi riil dai lingkungan terdekatnya. Berikutnya membawa siswa secara langsung mengenal serta mengayati lingkungan masyarakat, di mana mereka adalah merupakan bagian dari padanya. Tidak salah bila dikatakan bahwa pengajaran sejarah lokal mampu menerobos batas antara "dunia sekolah" dengan "dunia nyata" di luar sekolah. Dari pengajaran sejarah lokal siswa akan mendapatkan banyak contoh-contoh dan pengalamanpengalamandari berbagai tingkat perkembangan lingkungan masyarakatnya, termasuk situasi masa kininya. Mereka juga akan lebih terdorong mengembangkan keterampilan-keterampilan khusus seperti perihal observasi, teknik bertanya atau melakukan wawancara, menyeleksi sumber, mencari fakta, dll. Selama ini yang nyaring terdengar adalah pelajaran sejarah membosankan, penuh hafalan fakta-fakta, sehingga tidak menarik. Di samping adanya anggapan yang menyebutkan bahwa melalui pengajaran sejarah siswa dipaksa untuk mengungkapkan masa lalu. Padahal dengan belajar sejarah dapat diambil nilai-nilai kehidupan yang menuntun orang untuk menjalani kehidupan masa kini dan masa datang menjadi lebih baik.

Meskipun pengajaran sejarah lokal sangat mendukung usaha pengembangan kurikulum muatan lokal yang mengakrabkan siswa dengan lingkungan sekitarnya, sehingga juga tentunya akan mengakomodir kebutuhan daerah, namun keunggulan/ kelebihan tersebut di atas bukannya tanpa kendala yang sekaligus merupakan kelemahan-kelemahan dari pendekatan pengajaran ini. Beberapa hal yang perlu digaris bawahi antara lain pertama, adalah masalah sumber sejarah lokal itu sendiri berikut kemampuan siswa dalam memberikan penilainnya (analisis sumber). Kedua, adanya dilema antara memenuhi tuntutan kurikulum yang alokasi waktunya sangat ketat/ terbatas dengan proses penelitian hingga penulisan dalam bentuk laporan yang tentunya membutuhkan waktu yang relatif lama. Seperti diketahui kegiatan mengembangkan pengajaran sejarah lokal lebih banyak dilakukan di lapangan (di luar sekolah). Berikutnya ketiga, apa yang sudah dicapai melalui pengajaran sejarah lokal sering tidak sinkron ketika siswa 
menghadapi ujian yang bersifat nasional, dan sederet kendala lainnya.

Apa yang semestinya dilakukan oleh guru sebagai seorang yang memegang kendali selama proses belajar-mengajar di sekolah?. Kemauan serta disiplin kerja yang tinggi dari guru termasuk juga siswanya itulah kuncinya, jadi memang akhirnya bersumber pada gurusendiri. Ada bentuk pengajaran yang dapat diterapkan dari yang paling mudah sampai paling sulit. Termudah, guru cukup mengambil contoh-contoh dari kejadian lokal untuk memberi penjelasan dari materi sejarah nasional yang sedang diajarkan. Cara yang lain dengan mengajak siswa keluar sekolah melakukan penelitian dengan mengamati secara langsung sumbersumber sejarah serta mengumpulakn data sejarah (pergi ke museum, situs-situs sejarah, atau bahkan wawancara). Terakhir, berupa studi kasus yang perlu persiapan lebih lama dan bertahap (murid dilibatkan dalam memilih topik, membuat perencaan kegiatan, melaksanakan rencana tersebut sejak heuristik hingga tahap historiografi).

Dari ketiga bentuk pengajaran sejarah lokal di sekolah, yang kedualah yang relatif mendekati sasaran yakni tidak banyak memakan waktu, tetapi mengajak/ melibatkan siswa melakukan penelitian di luar sekolah meski dengan hal yang sederhana. Adapun yang menjadi pilihannya proses disini lebih diutamakan daripada hasil, dan tentunya adalah dalam memotivasi siswa mengembangkan keterampilan-keterampilan tertentu yang diperlukan ketika melakukan studi lapangan, sehingga belajar sejarah tidak membosankan lagi.

Pada dasarnya pembelajaran sejarah lokal agak berbeda dengan sejarah lokal itu sendiri. Sejarah lokal berarti proses kegiatan belajar di lingkungan pendidikan formal yang sasarannya adalah keberhasilan proses itu sendiri dalam mencapai tujuan yang telah ditetapkan sebelumnya dalam kurikulum. Sebaliknya, pembelajaran sejarah lokal adalah kegiatan dalam rangka pencapaian pengetahuan tentang peristiwa sejarah yang dijadikan sasaran studi dengan mengutamakan proses belajar yang punya sasaran-sasaran khusus yang jelas (Suharso,
2009: 6-7). Bahkan menurut Doudi, pengajaran sejarah lokal mampu menerobos batas antara dunia sosiologis-psikologis ketika peserta didik secara langsung mengenal dan menghayati lingkungan masyarakatnya di mana mereka bagian dari komunitas lingkungan (1967: 7-8).

Dalam pengajaran sejarah lokal peserta didik akan mendapatkan contohcontoh dan pengalaman-pengalaman dari berbagai tingkat perkembangan lingkungan masyarakatnya. Pendeknya, mereka akan lebih mudah menangkap konsep waktu atau perkembangan yang menjadi kunci penghubungan masa lampau, masa kini, dan masa mendatang.

Berdasarkan beberapa pilar CTL, maka jelas bahwa pembelajaran sejarah sangat relevan dengan teori-teori yang ada seperti teori J. Bruner tentang konsep pendekatan proses. Sesuai dengan sifat materi dan sumber sejarah lokal, maka peserta didik akan menjadi lebih peka terhadap lingkungan sosial dan budayanya. Peserta didik lebih pula terdorong mengembangkan ketrampilan khusus seperti mengobservasi, wawancara, mengumpulkan dan menyeleksi sumber, mengadakan klasifikasi dan mengidentifikasi konsep, serta melakukan generalisasi, yang mana semuanya ini mendorong bagi berkembangnya proses belajar yang bersifat inquiry (Suharso, 2009: 9).

Di samping kelebihan dan beberapa hal mendasar yang terkait dengan pembelajaran sejarah lokal, ada pula kelemahan-kelemahan yang terlihat ketika pengajar melaksanakan program pembelajaran sejarah lokal. Kelemahankelemahan itu adalah: pertama, sulitnya sumber dan bahan-bahan yang dapat dijadikan sebagai sasaran studi sejarah lokal. Setiap daerah mempunyai tingkat kesukaran yang berbeda mengingat kejadian-kejadian apa yang pernah terjadi di daerahnya juga tidak sama. Kedua, keterlambatan peserta didik menyelesaikan tugas penulisan laporan karena dibatasi kurikulum dan silabus. Seringkali pengajar harus mengalami kerepotan karena peserta didik tidak mengumpulkan tugas tepat pada waktunya. Kurikulum yang memberikan 
alokasi waktu yang terbatas tidak bisa memberikan peluang bagi peserta didik untuk berlama-lama. Di sisi lain peserta didik ingin memberikan laporan penulisan yang ideal dan berkualitas. Ketiga, pelaksanaan pembelajaran sejarah lokal menuntut pada pengajar untuk memiliki kedisiplinan dalam mengorganisasi kegiatannya seperti proses perencanaan, penentuan topik, persiapan, pelaksanaan kegiatan, dan penyusunan laporan hasil kegiatan. Hal ini berarti menuntut kemampuan dan kerja keras baik dari pengajar maupun peserta didik.

Pertama, tipe penyajian informasi sejarah lokal dari pengajar kepada peserta didik tanpa mengharuskan peserta didik berada di lapangan. Model dan tipe ini masih konvensional seperti metode pembelajaran sejarah lainnya yang mungkin membuat peserta didik tetap merasa jenuh dan bosan.Kedua, pengajar dapat membuat model penjelajahan lingkungan sekitar. Tipe ini dapat diterapkan pada peserta didik baik yang masih di sekolah dasar maupun sekolah menengah atas, walau dengan intensitas kedalaman materi dan riset yang berbeda. Ketiga, pengajar dapat menerapkan model lawatan sejarah sebagai upaya mengeksplorasi kekayaan sejarah lokal dan budaya yang dimilikinya. Menurut Susanto Zuhdi lawatan sejarah adalah suatu program penjelajahan masa lalu melalui kunjungan ke tempat-tempat bersejarah. Tempat bersejarah tersebut dapat berupa makam tokoh, tempat pengasingan, komunitas masyarakat, dan juga pusat-pusat kegiatan ekonomi (Lestariningsih, 2007: 3). Selain itu, pengajar dapat memanfaatkan museum daerah terdekat sebagai sasaran lawatan sejarah.

Keempat, pengajar dapat memilih model wisata sejarah sebagai sarana mengunjungi situs bersejarah. Model ini mirip sekali dengan lawatan sejarah. Pada model wisata sejarah, peserta didik menikmati obyek sejarah layaknya mereka sebagai turis dan berkesan rekreatif. Nuansa penikmatan terhadap panorama keindahan alam lebih ditonjolkan daripada unsur studinya (Nurjanto, 2007: 5). Kelima, pengajar dapat memilih model studi sejarah murni. Artinya, seorang pengajar memberi beban penugasan penelitian sejarah murni kepada peserta didik dengan pembatasanpembatasan yang sudah diprogramkan sebaik-baiknya. Namun sebelumnya agar tidak terjadi kebingungan peserta didik dan pemborosan waktu, sebaiknya pengajar memberikan dahulu tentang materi riset dan dasar-dasar penelitian sejarah. Keenam, pengajar memilih model kemah budaya untuk mengeksplorasi tema-tema sejarah lokal.

Berdasarkan berbagai model tersebut peneliti mengembangkan model penyajian informasi sejarah lokal dari pengajar kepada peserta didik tanpa mengharuskan peserta didik berada di lapangan. Model dan tipe ini masih konvensional seperti metode pembelajaran sejarah lainnya yang mungkin membuat peserta didik tetap merasa jenuh dan bosan sehingga untuk mengatasinya peneliti mengembangkannya dengan pembuatan media pembelajaran berbasis situs sejarah lokal Madiun. Bahan pembuatan media diperoleh dari lapangan dengan metode observasi dan dokumentasi. Bahan-bahan tersebut selanjutnya disusun secara tematik dan kronologis sehingga mudah diikuti dan dipahami.

Media pembelajaran berbasis situs sejarah lokal tersebut selanjutnya digunakan dalam pembelajaran oleh guru. Guru menampilkan media tersebut dalam pembelajaran, siswa mengamati dan mencermati isi media tersebut. Selanjutnya siswa masuk ke dalam kelompok-kelompok untuk mendiskusikan materi pembelajaran yang ditampilkan dalam media.

Setiap kelompok mempresentasikan hasil diskusinya di depan kelas sesuai topik yang menjadi tugasnya. Selesai presentasi, peserta lain memberi respon dalam bentuk pertanyaan, meminta penjelasan lanjut atau menambah data dan informasi baru yang belum terungkap.

Selanjutnya guru dan siswa melakukan evaluasi dan refleksi bersama. Evaluasi dan refleksi dikemas menjadi satu rangkaian kegiatan. Kegiatan ini dilakukan secara bersama oleh siswa dan guru, serta didukung oleh data catatan dari guru. Guru pendamping memfasilitasi kelebihan dan 
kekurangan mulai dari persiapan hingga pelaksanaan. Evaluasi dan refleksi akan menjadi pembelajaran bersama untuk merancang kegiatan selanjutnya. Siswa merasa tidak terbebani karena semua jawaban dan pernyataan diakomodasi sepanjang relevan dengan kerangka kegiatan. Setelah evaluasi dan refleksi dilakukan penutupan dengan cara yang kreatif dan menyenangkan pula.

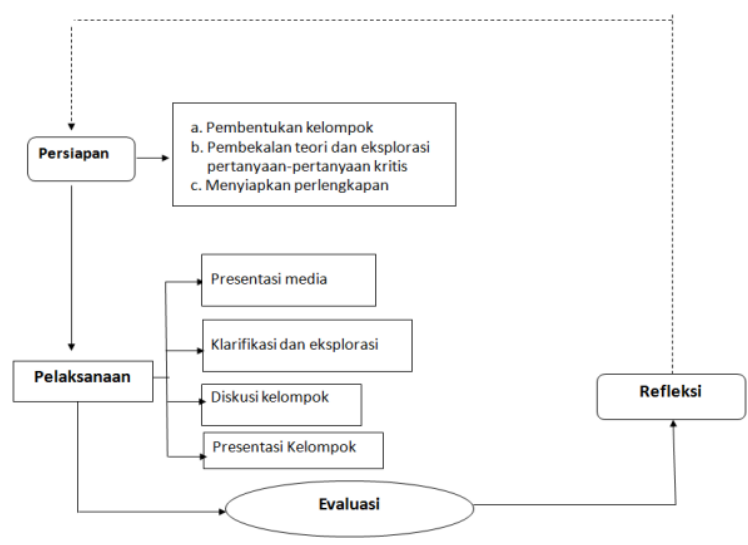

\section{Gambar Model Pembelajaran Berbasis Situs Sejarah Lokal}

\section{Penutup}

\section{A. Simpulan}

Berdasarkan berbagai model yang sudah ada, peneliti mengembangkan model penyajian informasi sejarah lokal dengan pembuatan media pembelajaran berbasis situs sejarah lokal Madiun. Media pembelajaran berbasis situs sejarah lokal tersebut selanjutnya digunakan dalam pembelajaran oleh guru. Guru menampilkan media tersebut dalam pembelajaran, siswa mengamati dan mencermati isi media tersebut. Selanjutnya siswa masuk ke dalam kelompok-kelompok untuk mendiskusikan materi pembelajaran yang ditampilkan dalam media. Setiap kelompok mempresentasikan hasil diskusinya di depan kelas sesuai topik yang menjadi tugasnya. Selesai presentasi, peserta lain memberi respon dalam bentuk pertanyaan, meminta penjelasan lanjut atau menambah data dan informasi baru yang belum terungkap.
Selanjutnya guru dan siswa melakukan evaluasi dan refleksi bersama.

Model Pembelajaran Berbasis Situs Sejarah Lokal tersebut di atas kemudian akan diujicobakan untuk melihat efektivitasnya sebagai sumber pembelajaran sejarah di sekolah menengah Kota Madiun. Model diujicobakan dalam skala kecil di 3 sekolah yang diambil secara random. Model diujicobakan dalam skala kecil kemudian diujicobakan dalam skala besar kepada masyarakat Madiun di 6 sekolah yang diambil dengan teknik random. Saran dan data yang masuk dari lapangan operasional digunakan untuk melakukan revisi terhadap produk akhir. Di akhir siklus ini produk didesiminasikan dan siap diimplementasikan. Diseminasi dilakukan melalui penulisan di jurnal ilmiah nasional terakreditasi (Jurnal Ilmu Pendidikan Universitas Negeri Malang).

\section{B. Saran}

Dalam rangka ujicoba model pembelajaran sejarah berbasis situs sejarah lokal ini, maka diharapkan sekolah-sekolah menengah di Kota Madiun, para guru sejarah dan siswa dapat berpartisipasi aktif sehingga dapat mendukung keberhasilan penelitian ini.

\section{Daftar Pustaka}

Agus Wibowo. 2010. Pentingnya Narasi Sejarah Lokal, dalam Harian Umum SOLOPOS Edisi Senin, 18 Januari 2010.

A. Hari Karyono. 1997. Kepariwisataan. Jakarta: Gramedia Widiasarana Indonesia.

Garraghan, Gilbert J. 1957. A Guide to Historical Method. New York: Fordham University Press.

Hariyono. 1995. Mempelajari Sejarah Secara Efektif. Jakarta: Pustaka Jaya.

Isjoni . 2007. Pembelajaran Sejarah. Bandung : Alfabeta.

Kuntowijoyo. 1994. Metodologi Sejarah. Yogyakarta: Tiara Wacana.

Sartono Kartodirdjo. "Suatu Tinjauan Fenomenologis tentang Folklore Jawa", dalam Soedarsono, ed.1986. Kesenian, Bahasa, dan Folklore 
Jawa. Yogyakarta: Departemen

Pendidikan dan Kebudayaan.

Soe Hok Gie. 1999. Orang-orang di

Persimpangan Kiri Jalan.

Yogyakarta: Bentang Budaya.

Taufik Abdullah. 1990. Sejarah Lokal di Indonesia. Yogyakarta: Gadjahmada University Press..

Wiendu Nuryanti. 1992. "Pariwisata dalam Masyarakat Tradisional". Makalah pada Program Pelatihan Perencanaan dan Pengembangan Pariwisata. Jakarta 